\title{
Fanconi Anemia Complementation Group Gene Mutation Negative
}

National Cancer Institute

\section{Source}

National Cancer Institute. Fanconi Anemia Complementation Group Gene Mutation

Negative. NCl Thesaurus. Code C159778.

A genetic finding indicating that Fanconi anemia complementation group gene mutations have not been detected in a sample. 